\title{
Effects of diet fermentability and supplementation of 2-hydroxy- 4-(methylthio)-butanoic acid and isoacids on milk fat depression: 1. Production, milk fatty acid profile, and nutrient digestibility
}

\author{
J. E. Copelin, ${ }^{1} \odot$ J. L. Firkins, ${ }^{2} \oplus$ M. T. Socha, ${ }^{3} \oplus$ and C. Lee ${ }^{1 *} \odot$ \\ ${ }^{1}$ Department of Animal Sciences, Ohio Agricultural Research and Development Center, The Ohio State University, Wooster 44691 \\ 2Department of Animal Sciences, The Ohio State University, Columbus 43210 \\ ${ }^{3}$ Zinpro Corporation, Eden Prairie, MN 55344
}

\begin{abstract}
The objectives of this experiment were to determine the effects of increased diet fermentability and polyunsaturated fatty acids (FA) with or without supplemental 2-hydroxy-4-(methylthio)-butanoic acid (HMTBa), isoacids (IA; isobutyrate, 2-methylbutyrate, isovalerate, and valerate) or the combination of these on milk fat depression (MFD). Ten Holstein cows (194 \pm 58 DIM, $691 \pm 69 \mathrm{~kg}$ BW, $28 \pm 5 \mathrm{~kg}$ milk yield) were used in a replicated $5 \times 5$ Latin square design. Treatments included a high-forage control diet (HF-C), a low-forage control diet (LF-C) causing MFD by increasing starch and decreasing neutral detergent fiber (NDF), the LF-C diet supplemented with HMTBa at $0.11 \%(28 \mathrm{~g} / \mathrm{d})$, the LF-C diet supplemented with IA at $0.24 \%$ of dietary dry matter $(60 \mathrm{~g} / \mathrm{d})$, and the LF-C diet supplemented with HMTBa and IA. Preplanned contrasts were used to compare HF-C versus LF-C and to examine the main effects of HMTBa or IA and their interactions within the LF diets. Dry matter intake was greater for LF-C versus HF-C, but milk yield remained unchanged. The LF-C diet decreased milk fat yield (0.87 vs. $0.98 \mathrm{~kg} / \mathrm{d}$ ) but increased protein yield compared with HF-C. As a result, energy-corrected milk was lower (28.5 vs. 29.6 $\mathrm{kg} / \mathrm{d}$ ) for LF-C versus HF-C. Although the concentration of total de novo synthesized FA in milk fat was not affected, some short- and medium-chain FA were lower for LF-C versus HF-C, but the concentrations of $\mathrm{C} 18$ trans-10 isomers were not different. Total-tract NDF apparent digestibility was numerically lower (42.4 vs. $45.6 \%)$ for LF-C versus HF-C. As the main effects, the decrease in milk fat yield observed in LF-C was alleviated by supplementation of HMTBa through increasing milk yield without altering milk fat content and by IA through increasing milk fat content without altering
\end{abstract}

Received May 24, 2020.

Accepted September 21, 2020.

*Corresponding author: lee.7502@osu.edu milk yield so that HMTBa or IA, as the main effects, increased milk fat yield within the LF diets. However, interactions for milk fat yield and ECM were observed between HMTBa and IA, suggesting no additive effect when used in combination. Minimal changes were found on milk FA profile when HMTBa was provided. However, de novo synthesized FA increased for IA supplementation. We detected no main effect of HMTBa, IA, and interaction between those on total-tract NDF digestibility. In conclusion, the addition of HMTBa and IA to a low-forage and high-starch diet alleviated moderate MFD. Although the mechanism by which MFD was alleviated was different between HMTBa and IA, no additive effects of the combination were observed on milk fat yield and ECM.

Key words: low-forage diet, methionine analog, branched-chain volatile fatty acids, valerate

\section{INTRODUCTION}

Milk fat depression (MFD) that is induced by dietary changes has been studied for decades, and among various theories proposed and studied, biohydrogenation-induced MFD, also called classical diet-induced MFD, has successfully explained MFD to some extent (Jenkins and Harvatine, 2014; Dewanckele et al., 2020). Biohydrogenation-induced MFD occurs with a shift of trans-11 to trans-10 C18 fatty acids (FA) - that is, alternate biohydrogenation pathway - directly inhibiting milk fat synthesis in mammary glands. This alternate biohydrogenation is enhanced when diet fermentability and PUFA content increase (Fuentes et al., 2009; Jenkins and Harvatine, 2014), causing severe MFD (Rico and Harvatine, 2013; Rico et al., 2015). However, changes in milk trans-10 C18 isomers do not fully explain MFD, indicating the existence of unknown other factors, and some cases of MFD have not been exactly characterized as the biohydrogenation-induced MFD (Dewanckele et al., 2020). Moderate MFD has received less attention and could be one type of MFD that may 
be poorly explained by the biohydrogenation theory (Baldin et al., 2018).

2-Hydroxy-4-(methylthio)-butanoic acid (HMTBa) was originally designed as a methionine precursor to support milk protein synthesis (Lobley et al., 2006), but meta-analyses indicated that HMTBa often increased milk fat yield (Zanton et al., 2014; Feng et al., 2018). This effect of HMTBa is different from the effect of rumen-protected methionine or D- or L-methionine infusion into the abomasum, the major effect of which was an increase in milk protein yield (Zanton et al., 2014). Recently, supplementing MFD-inducing diets with HMTBa has been shown to alleviate risk of MFD in high-producing cows (Baldin et al., 2018; Pitta et al., 2020).

Branched-chain VFA (isobutyric, isovaleric, and 2-methylbutyric; BCVFA) and valerate (a straightchain acid) are commonly referred to as isoacids (IA) produced during feed fermentation in the rumen and are growth factors especially for cellulolytic bacteria (Allison et al., 1962a,b; Dehority et al., 1967). Supplementation of IA (either individual BCVFA, all BCVFA, or IA) have often been shown to increase milk fat, milk yield, and fiber degradability in vitro and in vivo (Rogers et al., 1989; Yang, 2002; Wang et al., 2012). During in vitro studies by Kone et al. (1989) and Yang (2002), IA supply increased acetate and total VFA production, and increased NDF digestibility was also observed. This could be an evidence of IA stimulating milk fat synthesis because acetate supplementation can increase milk fat synthesis (Urrutia et al., 2019). Previous in vivo studies (Papas et al., 1984; Peirce-Sandner et al., 1985; Liu et al., 2018; Wang et al., 2019) also showed that supplemental IA increases fiber digestion or milk fat yield in dairy cows and could be effective in alleviating MFD.

We expected that increased diet fermentability with PUFA supplementation would cause moderate MFD in low-producing cows, resulting from alternate biohydrogenation pathways. Supplementing an MFD-inducing diet with HMTBa and IA was hypothesized to reduce risk of MFD, and the combination of the 2 supplements was predicted to have an additive effect. The objective of this study was to determine milk production, FA profile, and nutrient digestibility in lactating cows fed MFD-inducing diets supplemented with HMTBa and IA to test these hypotheses.

\section{MATERIALS AND METHODS}

\section{Animals, Diets, and Experimental Design}

The experiment was performed at Krauss Dairy Research Center at Agricultural Research and Devel- opment Center, The Ohio State University (Wooster, $\mathrm{OH})$. All procedures involving animals and their care were approved (2018A00000116) by the Institutional Animal Care and Use Committee of The Ohio State University.

A total of 10 multiparous lactating Holstein cows (mean \pm SD: $194 \pm 58$ DIM, $691 \pm 69 \mathrm{~kg} \mathrm{BW}$, and $28 \pm 5 \mathrm{~kg} / \mathrm{d}$ milk yield) were used in a replicated $5 \times$ 5 Latin square design (balanced) and housed in individual tie stalls. Square 1 included 5 noncannulated cows, and square 2 included 5 cannulated cows that were used to evaluate ruminal fermentation characteristics, FA profile, and bacterial community data, which were presented in our companion paper (Lee et al., 2021). The experiment consisted of 5 periods with $21 \mathrm{~d}$ per period $(14 \mathrm{~d}$ for adaption and $7 \mathrm{~d}$ for sampling). As shown in Table 1, dietary treatments included a relatively high-forage and low-starch control diet with $1.5 \%$ safflower oil (HF-C); a relatively low-forage and high-starch control diet with $1.5 \%$ safflower oil (LF-C); the LF-C diet supplemented with $0.11 \%$ of HMTBa in dietary DM $(28 \mathrm{~g} / \mathrm{d}$; Adisseo, Antony, France; LF-HMTBa); the LF-C diet supplemented with $0.24 \%$ of IA in dietary DM (Zinpro Corp., Eden Prairie, MN), supplying about $60 \mathrm{~g} / \mathrm{d}$ of IA $(17 \mathrm{~g} / \mathrm{d}$ of isobutyrate, $17 \mathrm{~g} / \mathrm{d}$ of 2-methylbutyrate, $12 \mathrm{~g} / \mathrm{d}$ of isovalerate, and $14 \mathrm{~g} / \mathrm{d}$ of valerate; LF-IA); and LF-C plus the combination of HMTBa and IA (LF-COMB). All diets included safflower oil (about $70 \%$ linoleic acid content; Jedwards International Inc., Braintree, MA) to provide linoleic acid (about 37\% linoleic acid of total dietary FA). Diets were formulated to meet or exceed the requirement of all nutrients for cows of $24 \mathrm{~kg} / \mathrm{d}$ DMI, $35 \mathrm{~kg} / \mathrm{d}$ milk yield, and $700 \mathrm{~kg} \mathrm{BW}$, according to NRC (2001). The concentrates were prepared for each diet, mixed daily with forages as a TMR, and fed to cows for ad libitum intake with orts targeted at about $5 \%$. Cows had free access to water and were milked twice daily at 0400 and $1600 \mathrm{~h}$.

\section{Sampling Procedure}

Forages were sampled weekly and dried at $100^{\circ} \mathrm{C}$ overnight, and DM of forages were used to adjust diets weekly. Concentrates and forages were sampled once a week, and orts from individual cows were sampled on d 19 to 21 in each period. Feed samples were composited by period, and orts samples were composited by cow within period for chemical analyses later.

Spot fecal and urine samples were collected from individual cows (total 6 spot samples per cow; about 300 $\mathrm{g}$ of sample at each event) on d 18 to 21 in each period to represent every 4 -h sampling in a 24 -h cycle (Morris 
et al., 2018; Lee et al., 2019). Fecal samples collected at each time point were composited on an equal wetweight basis by cow and period. Each spot urine sample collected through vulva stimulation was acidified with $2 \mathrm{M} \mathrm{H}_{2} \mathrm{SO}_{4}$ and composited on an equal-weight basis by cow and period.

Samples of milk were taken weekly and milk composition determined (milk fat, true protein, lactose, and MUN; B2000 infrared analyzer, Bentley Instruments, Chaska, MN) by DHI Cooperative Inc. (Columbus, $\mathrm{OH})$. Additional milk samples during a.m. and p.m. milking were collected on d 16 and 17 , composited, and centrifuged at $17,800 \times g$ for $30 \mathrm{~min}$ at $4^{\circ} \mathrm{C}$; the fat cake was removed and frozen at $-20^{\circ} \mathrm{C}$ for determination of FA profile. Another set of milk samples was collected during a.m. and p.m. milkings on d 18 to 20 and immediately analyzed for total $\mathrm{N}$.

\section{Laboratory Analyses}

Composite feed ingredients, refusals, and fecal samples were dried at $55^{\circ} \mathrm{C}$ for $72 \mathrm{~h}$ and ground to pass a 1-mm screen (Wiley mill; Arthur H. Thomas Co., Philadelphia, PA). Dried and ground fecal samples were analyzed for DM at $100^{\circ} \mathrm{C}$ (method 934.01; AOAC International, 2000), ash (method 942.05; AOAC International, 2000), N (Morris et al., 2019), and NDF (amylase, sodium sulfite; Ankom200 Fiber Analyzer; Ankom Technology Corp., Fairport, NY). In addition, feeds, refusals, and feces were analyzed for indigestible NDF as described by Huhtanen et al. (1994), with the following modification. Samples were weighed in quadruplicate into filter bags $(25-\mu \mathrm{m}$ pore size; Ankom Technology Corp.) and incubated in 2 cannulated lactating Holstein cows (about 60\% forage and $40 \%$

Table 1. Ingredient and chemical composition of diets

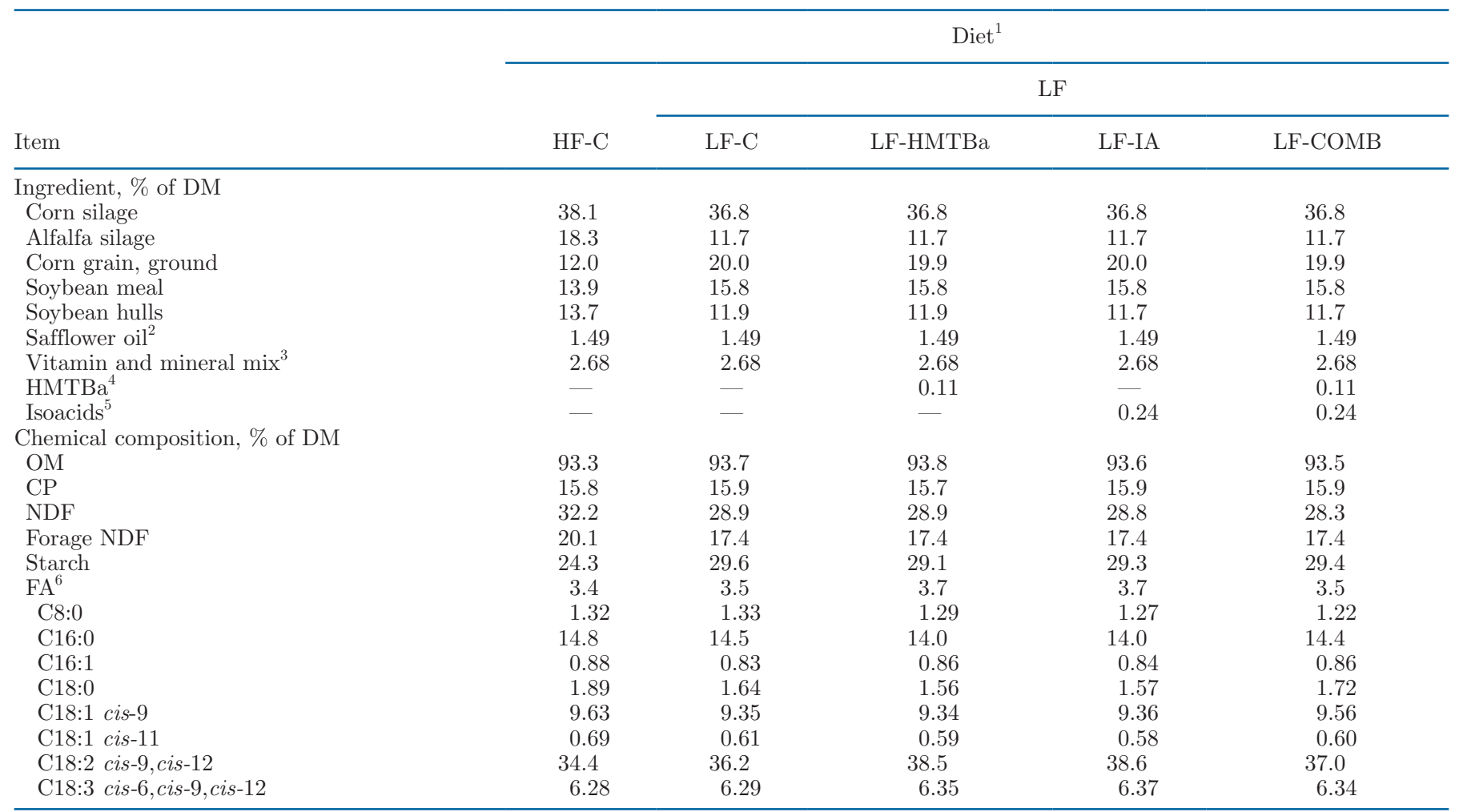

${ }^{1} \mathrm{HF}-\mathrm{C}=$ high-forage and low-starch diet; LF = low-forage and high-starch diets; LF-C = low-forage and high-starch diet with no supplementation; LF-HMTBa = LF-C diet supplemented with 2-hydroxy-4-(methylthio)-butanoic acid (HMTBa); LF-IA = LF-C diet supplemented with isoacids (IA); LF-COMB = LF-C diet supplemented with HMTBa and IA.

${ }^{2}$ Jedwards International Inc., Raintree, MA.

${ }^{3}$ Contained $38 \%$ trace mineral premix (39.3\% sodium, $53.2 \%$ chloride, $70 \mathrm{mg} / \mathrm{kg}$ cobalt, $400 \mathrm{mg} / \mathrm{kg}$ copper, $70 \mathrm{mg} / \mathrm{kg}$ iodine, $1,750 \mathrm{mg} / \mathrm{kg}$ iron, $2,800 \mathrm{mg} / \mathrm{kg}$ manganese, $200 \mathrm{mg} / \mathrm{kg}$ Se, and 3,500 mg/kg zinc), $30 \%$ limestone, $24 \%$ dicalcium phosphate, $0.55 \%$ vitamin A (30 kIU/g), $1.6 \%$ vitamin $\mathrm{D}(3 \mathrm{kIU} / \mathrm{g})$, and $2.0 \%$ vitamin $\mathrm{E}(44 \mathrm{IU} / \mathrm{g})$.

${ }^{4} 2$-Hydroxy-4-(methylthio)-butanoic acid (Rhodiment, Adisseo, Antony, France).

${ }^{5}$ Contained $7.3 \%$ isobutyrate, $7.2 \%$ 2-methylbutyrate, $4.9 \%$ isovalerate, and $5.9 \%$ valerate (Zinpro Corp., Eden Prairie, MN).

${ }^{6} \mathrm{FA}=$ fatty acid, $\%$ of total fatty acids. 
concentrate; similar to HF-C without safflower oil) for $12 \mathrm{~d}$. After incubation, bags were rinsed with cold water and analyzed for NDF. Total fecal output was estimated using indigestible NDF intake and fecal indigestible NDF content. Urine samples were analyzed for total N (Morris et al., 2019), creatinine (Cayman Chemical, Ann Arbor, MI), and urea N (Kit UR107; Randox Laboratories Ltd., Crumlin, UK). Daily urine excretion was estimated based on urinary creatinine concentration using creatinine excretion rate of 29.0 $\mathrm{mg} / \mathrm{kg}$ of BW (Valadares et al., 1999; Tebbe and Weiss, 2018). Milk samples were analyzed for total N (Morris et al., 2019). Milk FA profile was determined using the methylation procedure by Jenkins (2010), with separation by gas chromatography (HP 5890 series, Agilent Technologies, Santa Clara, CA) using a CP-SIL88 capillary column $(100 \mathrm{~m} \times 0.25 \mathrm{~mm} \times 0.2-\mu \mathrm{m}$ film thickness; Varian Inc., Palo Alto, CA). Individual FA were quantified based on the areas after normalizing the internal standard (C19:0), but recovery factors for individual FA were not determined and adjusted (for example, see Urrutia and Harvatine, 2017). We also noticed that the methylation method used here may have caused losses of shorter-chain FA (especially C4:0 and C6:0), although those FA were not likely lost, based on their concentrations in milk compared with those from the sodium methoxide methylation in the literature (Urrutia and Harvatine, 2017).

\section{Statistical Analysis}

Data from 1 cannulated cow in period 3 on the LF treatment were removed from statistical analysis due to mastitis. This cow recovered quickly and completed period 4. All cows (cannulated and noncannulated) were used to obtain data for nutrient digestibility, milk production, and milk FA profiles.

Milk yield, DMI, and feed efficiency data collected during the last $7 \mathrm{~d}$ of each period were used for statistical analysis using the MIXED procedure of SAS (SAS 9.4; SAS Institute Inc., Cary, NC). The mixed model included the fixed effects of treatment, period, day, and treatment by day interaction; it also included the random effects of square and cow within square. Day was used for repeated measures with the covariance structure of autoregressive order (1) according to the lowest Akaike information criterion. Degrees of freedom were adjusted using the option of Kenward-Roger. Data of milk composition, nutrient digestibility, and milk fatty acid profiles were analyzed using the same model, except that repeated measures were not included.

Preplanned contrasts were used to determine the difference between HF-C and LF-C. The main effect of HMTBa (LF-HMTBa and LF-COMB vs. LF and LF-IA), IA (LF-IA and LF-COMB vs. LF and LFHMTBa), and their interaction were tested. Therefore, effects of HMTBa or IA are referred to as the main effects of HMTBa or IA, respectively, in the Results and Discussion sections. When an interaction was $P \leq$ 0.10 , the PDIFF option generated pairwise comparisons among treatments (i.e., Fisher's protected least significant difference). Statistical differences were declared at $P \leq 0.05$. Differences between treatments with $0.05<$ $P \leq 0.10$ were considered as trends toward significance.

\section{RESULTS}

\section{Dry Matter Intake, Milk Production, and Milk Composition}

The LF-C diet increased (25.3 vs. $24.8 \mathrm{~kg} / \mathrm{d} ; P=$ 0.04) DMI compared with HF-C (Table 2), but milk yield was not affected. Milk fat content $(P=0.03)$ and milk fat yield (0.87 vs. $0.98 \mathrm{~kg} / \mathrm{d} ; P<0.01)$ decreased for LF-C versus HF-C, resulting in decreases in ECM $(P=0.03)$ for LF-C versus HF-C. Milk protein concentration and yield were greater $(P \leq 0.01)$ for $\mathrm{LF}-\mathrm{C}$ compared with HF-C. The main effects of HMTBa or IA had no effect on DMI, but a tendency $(P=0.08)$ for an interaction existed between HMTBa and IA. Milk yield tended to increase $(30.1$ vs. $29.4 \mathrm{~kg} / \mathrm{d} ; P=0.06)$ for HMTBa but was not affected by IA within the LF diets. An interaction $(P=0.01)$ was found between HMTBa and IA for milk yield. We detected no main effect of HMTBa on milk protein content and yield, but IA decreased (1.01 vs. $1.04 \mathrm{~kg} / \mathrm{d} ; P=0.04)$ milk protein yield within the LF diets without an interaction between HMTBa and IA. Supplementation of HMTBa did not affect milk fat content but increased $(P<0.01)$ milk fat yield. Although milk fat content was not affected by IA, milk fat yield increased $(P<0.01)$ for IA within the LF diets. An interaction $(P<0.01)$ for milk fat yield between HMTBa and IA was detected. The main effects of HMTBa and IA were not significant for lactose yield, but HMTBa and IA interacted $(P$ $<0.01)$. No difference in MUN was observed among treatments.

\section{Milk Fatty Acid Concentrations and Yield}

Changes in milk FA profile were observed by treatments (Table 3). For LF-C, the concentration of C6:0 and $\mathrm{C} 8: 0$ decreased $(P=0.01)$, and that of $\mathrm{C} 14$ :0 tended to decrease $(P=0.09)$, but total de novo synthesized FA showed only numerical decreases $(P=0.18)$ compared with HF-C. The concentration of linoleic acid 
Table 2. Effects of supplementing a diet inducing milk fat depression with 2-hydroxy-4-(methylthio)-butanoic acid (HMTBa) and isoacids (IA) on intake and milk production and composition of lactating cows $(\mathrm{n}=10)$

\begin{tabular}{|c|c|c|c|c|c|c|c|c|c|c|}
\hline Item & \multicolumn{5}{|c|}{$\operatorname{Diet}^{1}$} & SEM & & & & \\
\hline $\mathrm{BW}, \mathrm{kg}$ & 755 & 759 & 763 & 768 & 762 & 26.1 & 0.47 & 0.80 & 0.28 & 0.16 \\
\hline BW change, $\mathrm{kg} / \mathrm{d}$ & 1.1 & 1.0 & 0.90 & 1.0 & 1.0 & 0.25 & 0.69 & 0.75 & 0.67 & 0.84 \\
\hline DMI, $\mathrm{kg} / \mathrm{d}$ & 24.8 & 25.3 & 25.8 & 25.9 & 25.7 & 1.05 & 0.04 & 0.79 & 0.29 & 0.08 \\
\hline $\mathrm{ECM} / \mathrm{DMI}, \mathrm{kg} / \mathrm{kg}$ & 1.19 & 1.12 & 1.20 & 1.17 & 1.15 & 0.20 & $<0.01$ & 0.07 & 0.78 & $<0.01$ \\
\hline \multicolumn{11}{|l|}{ Milk composition } \\
\hline Fat, \% & 3.38 & 2.97 & 3.27 & 3.41 & 3.23 & 0.20 & 0.03 & 0.63 & 0.13 & 0.09 \\
\hline True protein, $\%$ & 3.37 & 3.51 & 3.41 & 3.40 & 3.45 & 0.09 & 0.04 & 0.56 & 0.43 & 0.07 \\
\hline Lactose, \% & 4.74 & 4.79 & 4.78 & 4.77 & 4.78 & 0.09 & 0.39 & 0.82 & 0.86 & 0.59 \\
\hline Fat, $\mathrm{kg} / \mathrm{d}$ & 0.98 & 0.87 & 1.00 & 1.01 & 0.96 & 0.22 & $<0.01$ & 0.02 & $<0.01$ & $<0.01$ \\
\hline Protein, $\mathrm{kg} / \mathrm{d}$ & 0.98 & 1.02 & 1.05 & 1.01 & 1.01 & 0.18 & 0.01 & 0.26 & 0.04 & 0.46 \\
\hline
\end{tabular}

${ }^{1} \mathrm{HF}-\mathrm{C}=$ high-forage and low-starch diet; LF = low-forage and high-starch diet; LF-C = low-forage and high-starch diet with no supplementation; LF-HMTBa = LF-C diet supplemented with HMTBa; LF-IA = LF-C diet supplemented with IA; LF-COMB = LF-C diet supplemented with HMTBa and IA.

${ }^{2} \mathrm{CON}=\mathrm{HF}-\mathrm{C}$ vs. LF-C; HMTBa = main effect of HMTBa in the LF diets; IA = main effect of IA in the LF diets; INT = interaction of HMTBa with IA.

${ }^{3} \mathrm{ECM}(\mathrm{kg} / \mathrm{d})=\mathrm{kg}$ of milk $\times[(38.3 \times \%$ fat $\times 10+24.2 \times \%$ true protein $\times 10+16.54 \times \%$ lactose $\times 10+20.7) / 3,140](\mathrm{Sjaunja}$ et al., 1990$)$.

(18:2 cis-9, cis-12) was greater (4.48 vs. $3.80 \%$ of total FA; $P<0.01$ ) for LF-C versus HF-C. As the main effect, HMTBa had no effect on milk FA profile within the LF diets, including C18 trans-10 or 11 isomers. As the main effect, IA supplementation increased (29.3 vs. $27.4 \%$ of total FA; $P=0.01$ ) the concentration of de novo synthesized FA (C6:0, C8:0, C10:0, C12:0, C14:0, and $\mathrm{C} 15: 0)$ and decreased $(P=0.03)$ that of preformed FA (C17:0 iso, linoleic acid, and various cis or trans C18:1) within the LF diets. In addition, IA decreased $(P=0.04)$ trans-11 C18:1 and tended to decrease cis9,trans-11 C18:1 within the LF diets. A tendency of interactions $(P \leq 0.10)$ between HMTBa and IA for minor FA was observed.

\section{Nitrogen Balance and Total-Tract Apparent Nutrient Digestibility}

No major differences in dietary $\mathrm{N}$ utilization for milk $\mathrm{N}$ and excretion in feces and urine were detected among treatments (Table 4) except those between LF-C and HF-C. The LF-C diet had greater $(P=0.01) \mathrm{N}$ intake and tended to have lower (35.1 vs. $38.1 \% ; P=0.06$ ) fecal and (30.9 vs. $33.2 \% ; P=0.05)$ urinary $\mathrm{N}$ excretion as percentages of $\mathrm{N}$ intake compared with HF-C. This resulted in an increase in the amount of $\mathrm{N}$ retained (58.5 vs. $18.8 \mathrm{~g} / \mathrm{d} ; P=0.01)$ and retained $\mathrm{N}$ as proportion of N intake (8.6 vs. $2.9 \%$; $P=0.05$ ) for LF-C com- pared with HF-C. However, no main effects of HMTBa or IA and their interaction was observed on dietary $\mathrm{N}$ utilization and excretion, which suggests that all of the LF diets supported greater $\mathrm{N}$ retention compared with cows fed the HF-C diet. Apparent total-tract nutrient digestibility did not differ among treatments. However, compared with HF-C, LF-C numerically decreased (42 vs. $46 \% ; P=0.12$ ) NDF digestibility (Table 5 ), and neither HMTBa nor IA had significant main effects. No interactions for nutrient digestibility were observed.

\section{DISCUSSION}

In the current study, the MFD-inducing control diet (i.e., LF-C) was obtained by lowering NDF (32 to $29 \%$; forage NDF from 20 to $17 \%$ on a DM basis) and increasing starch concentration from 24 to $29 \%$ in dietary DM compared with HF-C. Safflower oil (1.5\% of dietary DM) was also included in LF-C as a source of PUFA (mainly linoleic acid). Safflower oil was included in the HF-C diet at the same inclusion rate as in LF-C, to examine whether or not alternate biohydrogenation is enhanced under $\mathrm{LF}-\mathrm{C}$ versus HF-C. The inclusion rate of isobutyrate, 2-methylbutyrate, isovalerate, and valerate for IA was based on previous studies by Papas et al. (1984) and Liu et al. (2018). Liu et al. (2018) recommended that equimolar proportions of BCVFA at total 60 g per day (excluding valerate) was the optimal, 
based on a dose response of milk production to BCVFA. The inclusion rate of $0.1 \%$ HMTBa in dietary DM was used according to previous studies (Baldin et al., 2018; Pitta et al., 2020) in which MFD was alleviated by supplementing MFD-inducing diets with HMTBa.

\section{Effects of LF-C Versus HF-C}

Cows fed LF-C had moderate MFD, as designed, compared with those fed HF-C. The degrees of the decreases in milk fat content and yield were only 12 and

Table 3. Effects of supplementing a diet inducing milk fat depression with 2-hydroxy-4-(methylthio)-butanoic acid (HMTBa) and isoacids (IA) on milk fatty acid profile of lactating cows $(\mathrm{n}=10)$

\begin{tabular}{|c|c|c|c|c|c|c|c|c|c|c|}
\hline \multirow{2}{*}{ Fatty acid, $\mathrm{g} / 100 \mathrm{~g}$} & \multicolumn{5}{|c|}{$\operatorname{Diet}^{1}$} & \multirow{2}{*}{ SEM } & \multirow{2}{*}{\multicolumn{4}{|c|}{$P$-value ${ }^{2}$}} \\
\hline & $\mathrm{HF}-\mathrm{C}$ & \multicolumn{4}{|c|}{$\mathrm{LF}$} & & & & & \\
\hline $4: 0$ & 5.36 & 5.50 & 4.90 & 5.48 & 5.49 & 0.415 & 0.79 & 0.23 & 0.29 & 0.39 \\
\hline 6:0 & 2.33 & 1.91 & 1.97 & 2.26 & 2.12 & 0.155 & 0.02 & 0.62 & 0.03 & 0.26 \\
\hline 8:0 & 1.09 & 0.83 & 0.91 & 1.02 & 1.04 & 0.103 & 0.01 & 0.38 & 0.01 & 0.56 \\
\hline 13:0 iso & 0.03 & 0.05 & 0.05 & 0.03 & 0.06 & 0.018 & 0.59 & 0.36 & 0.97 & 0.52 \\
\hline 13:0 anteiso & 0.08 & 0.08 & 0.07 & 0.08 & 0.08 & 0.007 & 0.75 & 0.58 & 0.52 & 0.18 \\
\hline $13: 0$ & 0.08 & 0.11 & 0.10 & 0.08 & 0.13 & 0.014 & 0.14 & 0.16 & 0.92 & 0.05 \\
\hline 14:0 iso & 0.09 & 0.07 & 0.08 & 0.09 & 0.09 & 0.016 & 0.21 & 0.65 & 0.39 & 0.66 \\
\hline $14: 0$ & 10.6 & 10.1 & 10.5 & 10.9 & 10.9 & 0.26 & 0.09 & 0.48 & 0.02 & 0.43 \\
\hline $15: 0$ iso & 0.49 & 0.45 & 0.47 & 0.47 & 0.41 & 0.028 & 0.24 & 0.37 & 0.33 & 0.10 \\
\hline 15:0 anteiso & 1.04 & 1.23 & 1.21 & 0.92 & 1.15 & 0.112 & 0.16 & 0.30 & 0.11 & 0.23 \\
\hline 16:1 and $17: 0$ anteiso & 1.67 & 1.96 & 1.80 & 1.52 & 1.72 & 0.170 & 0.13 & 0.86 & 0.11 & 0.26 \\
\hline $17: 0$ & 0.48 & 0.47 & 0.50 & 0.50 & 0.47 & 0.029 & 0.73 & 0.91 & 0.96 & 0.35 \\
\hline $18: 0$ & 9.82 & 9.11 & 9.63 & 10.15 & 9.41 & 0.449 & 0.26 & 0.77 & 0.42 & 0.20 \\
\hline $18: 1$ trans -4 and -5 & 0.06 & 0.03 & 0.03 & 0.03 & 0.03 & 0.014 & 0.13 & 0.54 & 0.41 & 0.60 \\
\hline $18: 1$ trans -6 and -8 & 0.57 & 0.67 & 0.53 & 0.56 & 0.37 & 0.067 & 0.28 & 0.03 & 0.07 & 0.74 \\
\hline $18: 1$ trans -10 & 1.52 & 1.87 & 1.55 & 1.65 & 2.06 & 0.445 & 0.50 & 0.87 & 0.78 & 0.39 \\
\hline 18:1 trans- 11 & 2.23 & 2.49 & 2.22 & 2.04 & 1.73 & 0.207 & 0.38 & 0.19 & 0.04 & 0.91 \\
\hline 18:1 trans -12 & 0.77 & 0.78 & 0.71 & 0.72 & 0.69 & 0.033 & 0.71 & 0.15 & 0.18 & 0.44 \\
\hline $18: 1$ cis-9 & 18.7 & 19.3 & 19.4 & 18.0 & 18.3 & 0.723 & 0.45 & 0.51 & 0.04 & 0.70 \\
\hline 18:1 cis-11 & 0.47 & 0.52 & 0.47 & 0.45 & 0.43 & 0.023 & 0.10 & 0.21 & 0.01 & 0.74 \\
\hline $18: 1$ cis- 12 & 0.51 & 0.64 & 0.57 & 0.54 & 0.61 & 0.044 & 0.01 & 0.96 & 0.37 & 0.09 \\
\hline $18: 1$ cis-13 & 0.81 & 0.78 & 0.74 & 0.71 & 0.62 & 0.050 & 0.71 & 0.17 & 0.06 & 0.68 \\
\hline 18:1 cis-15 & 0.38 & 0.35 & 0.38 & 0.37 & 0.35 & 0.015 & 0.22 & 0.93 & 0.59 & 0.10 \\
\hline $18: 2$ cis- 9, cis- 12 & 3.80 & 4.48 & 4.25 & 4.02 & 4.03 & 0.172 & $<0.01$ & 0.56 & 0.02 & 0.30 \\
\hline $20: 3 n-3$ & 0.005 & 0.003 & 0.002 & 0.004 & 0.007 & 0.0042 & 0.56 & 0.76 & 0.41 & 0.56 \\
\hline $20: 3 n-6$ & 0.18 & 0.16 & 0.16 & 0.19 & 0.15 & 0.016 & 0.39 & 0.29 & 0.49 & 0.44 \\
\hline Other & 4.48 & 4.76 & 4.81 & 4.65 & 4.42 & 0.173 & 0.25 & 0.68 & 0.15 & 0.41 \\
\hline$\Sigma \mathrm{OBCFA}^{3}$ & 5.60 & 6.03 & 5.99 & 5.37 & 5.84 & 0.272 & 0.20 & 0.44 & 0.16 & 0.36 \\
\hline$\Sigma$ de novo $(<\mathrm{C} 16)$ & 28.7 & 27.3 & 27.4 & 29.3 & 29.3 & 1.07 & 0.18 & 0.97 & 0.01 & 0.86 \\
\hline इpreformed (>C16) & 43.0 & 44.5 & 43.9 & 42.4 & 41.9 & 1.27 & 0.30 & 0.75 & 0.03 & 0.78 \\
\hline$\Sigma 16$ & 25.1 & 25.0 & 25.2 & 25.4 & 25.7 & 1.15 & 0.88 & 0.90 & 0.48 & 0.90 \\
\hline
\end{tabular}

${ }^{1} \mathrm{HF}-\mathrm{C}=$ high-forage and low-starch diet; LF $=$ low-forage and high-starch diet; LF-C = low-forage and high-starch diet with no supplementation; LF-HMTBa = LF-C diet supplemented with HMTBa; LF-IA = LF-C diet supplemented with IA; LF-COMB = LF-C diet supplemented with HMTBa and IA.

${ }^{2} \mathrm{CON}=\mathrm{HF}-\mathrm{C}$ vs. LF-C; HMTBa = main effect of HMTBa in the LF diets; IA = main effect of IA in the LF diets; INT = interaction of HMTBa with IA.

${ }^{3}$ Sum of all odd- and branched-chain fatty acids. 
Table 4. Effects of supplementing a diet inducing milk fat depression with 2-hydroxy-4-(methylthio)-butanoic acid (HMTBa) and isoacids (IA) on nitrogen utilization and excretion of lactating cows $(n=10)^{1}$

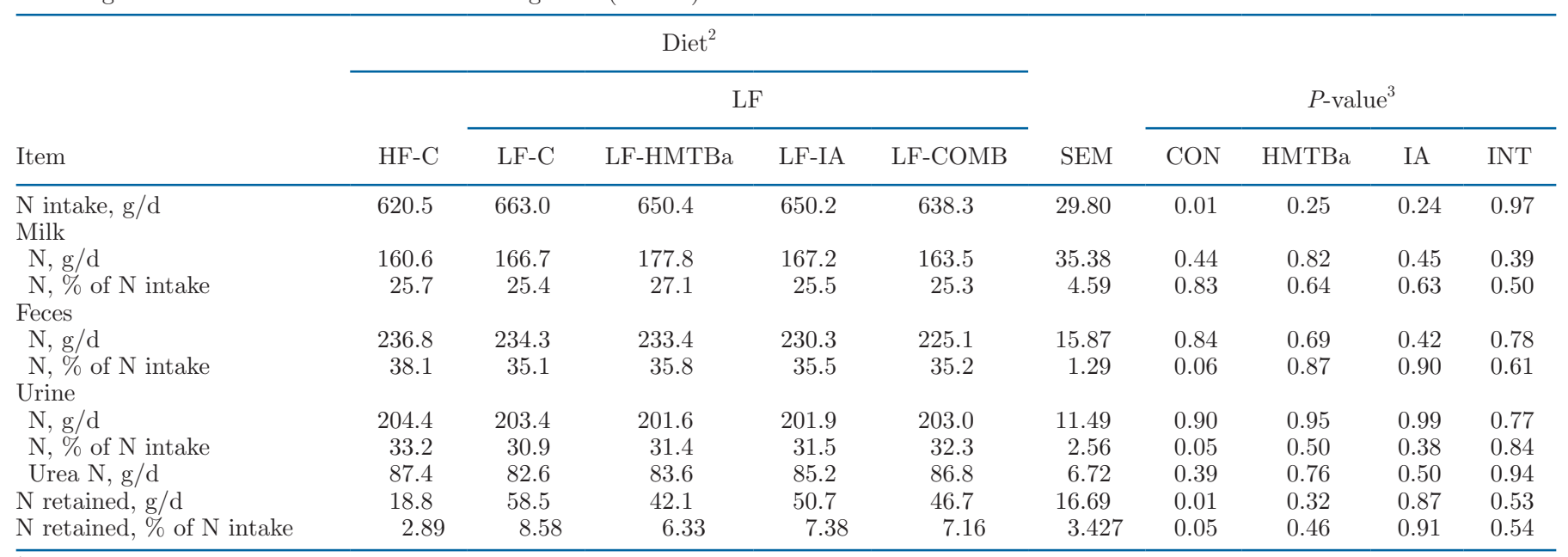

${ }^{1}$ Data of $\mathrm{N}$ intake measured during total collection of feces and urine were used (last $3 \mathrm{~d}$ in each period).

${ }^{2} \mathrm{HF}-\mathrm{C}=$ high-forage and low-starch diet; LF = low-forage and high-starch diet; LF-C = low-forage and high-starch diet with no supplementation; LF-HMTBa = LF-C diet supplemented with HMTBa; LF-IA = LF-C diet supplemented with IA; LF-COMB = LF-C diet supplemented with HMTBa and IA.

${ }^{3} \mathrm{CON}=\mathrm{HF}-\mathrm{C}$ vs. LF-C; HMTBa = main effect of HMTBa in the LF diets; IA = main effect of IA in the LF diets; INT = interaction of HMTBa with IA.

11\% compared with HF-C, which was less severe than biohydrogenation-induced MFD observed in previous studies (20 to $30 \%$ decreases in milk fat yield) with similar dietary changes (Baldin et al., 2018; Pitta et al., 2020). As expected, the lower MFD for LF-C likely occurred because our cows were low-producing (average $29 \mathrm{~kg} / \mathrm{d}$ milk yield) and therefore less susceptible to MFD when an MFD-inducing diet was fed, compared with high-producing cows (Baldin et al., 2018). Another reason for the moderate MFD for LF-C could be because supplemental PUFA (safflower oil) was included in the HF-C diet at the same inclusion rate as in LF-C. Ramirez Ramirez et al. (2015) reported that diet fermentability (increasing starch from about 19 to $23 \%$ ) and oil supplementation (soy oil) had similar contributions to severe MFD. In that study, relatively

Table 5. Effects of supplementing a diet inducing milk fat depression with 2-hydroxy-4-(methylthio)-butanoic acid (HMTBa) and isoacids (IA) on nutrient intake and apparent digestibility in lactating cows $(\mathrm{n}=10)^{1}$

\begin{tabular}{|c|c|c|c|c|c|c|c|c|c|c|}
\hline \multirow{2}{*}{ Item } & \multicolumn{5}{|c|}{$\operatorname{Diet}^{2}$} & \multirow{2}{*}{ SEM } & \multirow{2}{*}{\multicolumn{4}{|c|}{$P$-value ${ }^{3}$}} \\
\hline & $\mathrm{HF}-\mathrm{C}$ & \multicolumn{4}{|c|}{$\mathrm{LF}$} & & & & & \\
\hline \multicolumn{11}{|c|}{ Intake, $\mathrm{kg} / \mathrm{d}$} \\
\hline DM & 25.0 & 25.6 & 26.2 & 26.0 & 25.8 & 1.06 & 0.25 & 0.62 & 0.91 & 0.38 \\
\hline OM & 23.3 & 24.0 & 24.6 & 24.3 & 24.1 & 1.07 & 0.18 & 0.65 & 0.80 & 0.33 \\
\hline \multicolumn{11}{|c|}{ Apparent digestibility, \% } \\
\hline DM & 63.0 & 64.0 & 64.1 & 64.3 & 65.2 & 1.02 & 0.44 & 0.49 & 0.38 & 0.64 \\
\hline $\mathrm{OM}$ & 64.2 & 65.3 & 65.3 & 65.6 & 66.5 & 1.00 & 0.35 & 0.52 & 0.33 & 0.53 \\
\hline $\mathrm{CP}$ & 63.3 & 64.6 & 64.4 & 64.6 & 65.8 & 1.29 & 0.37 & 0.60 & 0.43 & 0.40 \\
\hline $\mathrm{NDF}$ & 45.6 & 42.4 & 43.3 & 42.0 & 44.6 & 1.67 & 0.12 & 0.19 & 0.73 & 0.52 \\
\hline
\end{tabular}

${ }^{1}$ Data of intake measured during total collection of feces were used (last $3 \mathrm{~d}$ in each period).

${ }^{2} \mathrm{HF}-\mathrm{C}=$ high-forage and low-starch diet; LF $=$ low-forage and high-starch diet; LF-C = low-forage and high-starch diet with no supplementation; LF-HMTBa = LF-C diet supplemented with HMTBa; LF-IA = LF-C diet supplemented with IA; LF-COMB = LF-C diet supplemented with HMTBa and IA.

${ }^{3} \mathrm{CON}=$ HF-C vs. LF-C; HMTBa = main effect of HMTBa in the LF diets; IA = main effect of IA in the LF diets; INT = interaction of HMTBa with IA. 
low-producing cows were used (about 33 and $27 \mathrm{~kg} / \mathrm{d}$ milk yield in experiments 1 and 2, respectively), and the basal diet contained relatively high PUFA $(2.5 \%$ in dietary DM) with corn distillers grain at $20 \%$ in the ration (DM basis). Therefore, their increased diet fermentability caused moderate MFD (17 and 13\% decrease in milk fat yield in experiments 1 and 2, respectively). Supplemental PUFA was also included in HF-C in this study, because our objective was to determine whether alternate biohydrogenation is enhanced when feeding a diet with low NDF and high starch, causing moderate MFD. Because of the same PUFA content between LF-C and HF-C, the possibilities for the moderate MFD observed for LF-C could be either increased diet fermentability (changes in ruminal $\mathrm{pH}$ and VFA profile), alternate biohydrogenation (e.g., trans-10 C18 isomers) enhanced by increased diet fermentability, or both.

Ruminal biohydrogenation capacity (at least first step of the biohydrogenation) may have been lower for LF-C versus HF-C due to greater concentration of C18:2 cis-9,cis-12 in milk for LF-C in the rumen. An in vitro study by Troegeler-Meynadier et al. (2014) found decreases in disappearance of C18:2 cis-9, cis-12 in rumen culture during the short-term incubation $(6$ h) for high-fermentable substrate and low $\mathrm{pH}$ compared with low-fermentable and high $\mathrm{pH}$, respectively. Milk FA concentrations of C18:1 trans-10 and C18:2 trans10, cis-12 were not different between LF-C and HF-C, suggesting that effects of altered ruminal biohydrogenation of PUFA on MFD were minor. This finding is also supported by the lack of differences in the concentrations of major biohydrogenation intermediates (C18 trans-10 and 11 isomers) in the rumen (6 h after feeding) shown in our companion study (Lee et al., 2021). However, the concentrations of various FA that are synthesized de novo in mammary glands were lower for LF-C versus HF-C, probably because of the short supply of precursors for FA synthesis in the mammary gland (e.g., acetate; Urrutia et al., 2019). In our companion study (Lee et al., 2021), LF-C decreased $(P=$ $0.10)$ molar concentration of acetate and increased $(P$ $=0.01)$ propionate in the rumen compared with HF-C, decreasing $(P=0.03)$ the ratio of acetate to propionate from 3.14 to 2.74 . This decreased ratio is also supported by a numerical decrease in total-tract NDF digestibility by 3 percentage-units for LF-C versus HF-C. Therefore, we concluded that the enhanced alternate biohydrogenation producing more $\mathrm{C} 18$ trans-10 isomers did not occur, and, instead, the moderate MFD for LF-C likely resulted from changes in rumen fermentation $(\mathrm{pH}$ and VFA profile) by increased diet fermentability. Changes in rumen bacterial community $(\alpha$-diversity and relative abundances of 16S rRNA gene sequences at phylum and genus levels) by LF-C versus HF-C are shown in our companion study (Lee et al., 2021). Despite the changes in rumen bacterial diversity and community, the sum of all the odd- and branched-chain FA in milk, which may be a potential marker for rumen microbial changes (Vlaeminck et al., 2006), was not different between LF-C and HF-C. Inconsistent results about changes in milk odd- and branched-chain FA during MFD have previously been observed (Ramirez Ramirez et al., 2016; Baldin et al., 2018; Pitta et al., 2020).

Cows fed the LF-C diet had greater DMI compared with HF-C. Complex factors are involved in regulating DMI (Allen, 2000), and the following 2 factors could be mainly associated with changes in DMI: increasing supply of rumen fermentable energy in a ration can decrease DMI (hepatic oxidation theory), and decreasing forage NDF can reduce gut fill and increase DMI (Allen, 2000). The latter may have been the case in this study. A $4 \%$ increase in milk protein yield for LF-C versus HF-C is in agreement with some (Sánchez-Duarte et al., 2019) but not all studies when diet fermentability was increased (Weiss et al., 2009). Body protein accretion in addition to milk protein yield may have increased as well for LF-C versus HF-C, as evidenced by lower $\mathrm{N}$ excretion in feces and urine (as percent of $\mathrm{N}$ intake), which resulted in increased $\mathrm{N}$ retention. However, BW and BW change do not support body protein accretion. Despite the increase in milk protein yield, ECM was decreased for LF-C due to a $12 \%$ decrease in milk fat yield compared with HF-C. In consequence, this resulted in decreased feed efficiency (ECM/DMI, $\mathrm{kg} / \mathrm{kg})$.

\section{Main Effect of HMTBa Within the LF Diets}

Supplementation of the LF diets with HMTBa (main effect of HMTBa) did not alter milk fat concentration but tended to increase milk yield from 28.4 to 30.1 $\mathrm{kg} / \mathrm{d}$, which resulted in increasing milk fat yield. We also observed no main effect of HMTBa in milk concentrations of C18:1 trans-11 and C18:2 trans-10, cis-12, which did not agree with our hypothesis. Baldin et al. (2018) observed changes in milk fat concentration of C18:1 trans-11 and C18:1 trans-10 (increasing by 35\% and decreasing by 50\%, respectively) when an MFDinducing diet was supplemented with HMTBa $(28.5 \%$ NDF, $29.2 \%$ starch, and $3.1 \%$ PUFA in dietary DM), alleviating MFD. In that study, however, MFD did not occur when the MFD-inducing diet was fed to low-producing cows (about $30 \mathrm{~kg} / \mathrm{d}$ milk yield), and HMTBa had no effect on milk concentrations of C18 trans-10 and trans-11 isomers. This explains, at least in 
part, the minimal changes in milk FA profile observed in response to HMTBa supplementation of a moderate MFD-inducing diet fed to relatively low-producing cows $(30 \mathrm{~kg} / \mathrm{d}$ milk yield) in the current study and indicates that the major factor causing moderate MFD could be other dietary factors, rather than an increase in biohydrogenation intermediates causing severe MFD. Previously, milk yield increased when cows were fed HMTBa in some studies (Hansen et al., 1991; Piepenbrink et al., 2004) but not others (Zanton et al., 2014; Feng et al., 2018). As a methionine precursor, it has been speculated that HMTBa has postabsorptive effects on milk yield and milk fat synthesis by serving as a methyl donor and increasing blood triglycerides rather than acting solely as a protein building block (Huber et al., 1984; Zanton et al., 2014). These potential postabsorptive effects of HMTBa may have alleviated MFD in the current study, and are supported by the lack of a main effect of HMTBa on total-tract NDF digestibility within the LF diets. However, ruminal effects of HMTBa on alleviating MFD cannot be ruled out, although minimal changes in rumen bacterial diversity and community (amplicon sequencing variants) were observed in response to HMTBa supplementation in our companion study (Lee et al., 2021). We discussed an increase in mass of rumen bacteria in our companion study (Lee et al., 2021) as a potential ruminal effect of HMTBa to alleviate MFD according to increased concentration of saturated FA and decreased concentrations of poly- and monounsaturated FA. An increase in microbial protein synthesis was observed previously when HMTBa was provided to lactating cows (Lee et al., 2015).

The observation of no changes in milk C18 trans-10 and 11 isomers for HMTBa under MFD contrasts with the results from Baldin et al. (2018) and Pitta et al. (2020). Again, this discrepancy can be partly explained by productivity of cows (i.e., high-producing cows vs. low-producing cows), as previously discussed. The reason for differing effects of HMTBa supplementation on milk FA profile when fed to low- and high-producing cows is not known. However, DMI for low-producing cows is much lower (about 12\%), altering rumen passage rate and feeding and ruminating behaviors, which might cause different responses to an MFD-inducing diet (Jenkins et al., 2008; Baldin et al., 2018). In the current study, because of an increase in milk fat with HMTBa supplementation, ECM production increased and ECM/DMI $(\mathrm{kg} / \mathrm{kg})$ tended to increase with HMTBa supplementation of LF diets. Milk protein content and yield were not affected by HMTBa. Supplemental HMTBa is a methionine precursor and often increases milk protein yield (Zanton et al., 2014), but not always
(Lee et al., 2015). Lack of effect of HMTBa on milk protein yield may indicate that methionine was not limiting for milk protein synthesis for the late-lactation cows used in this study. This is supported by the lack of a main effect of HMTBa on $\mathrm{N}$ metabolism (i.e., dietary $\mathrm{N}$ utilization and excretion) in the LF diets.

\section{Main Effects of IA Within the LF Diets}

As the main effect, supplementation of IA increased milk fat yield within the LF diets. This occurred via a mechanism which is different from the mechanism for HMTBa. Supplementation of IA increased milk fat yield by increasing milk fat content but not milk volume, and the increased milk fat content resulted from increased de novo synthesis of milk FA. Increased milk fat yield is consistent with results from most studies in which individual BCVFA, IA, or IA without valerate were fed to cows (Papas et al., 1984; Peirce-Sandner et al., 1985; Wang et al., 2019). Similar results were also observed in a study by Liu et al. (2018). In that study, a diet with $42 \%$ NDF and an estimated $24 \%$ starch (starch concentration not reported) was supplemented with IA (without valerate; 0, 30, 60, and 90 $\mathrm{g} / \mathrm{d}$ ). Increasing IA supplementation linearly increased milk fat content and yield and de novo synthesis of milk FA. In the current study, we detected no main effect of IA on C18:2 trans-10,cis-12 or C18:1 trans-10 in milk fat, directly inhibiting de novo FA synthesis (Jenkins and Harvatine, 2014). Therefore, the increase in de novo synthesized FA in milk fat for IA could be the main reason for MFD alleviation for IA. However, in our companion study (Lee et al., 2021), we observed increased concentrations of C18:2 trans-10,cis-12 and C18:1 trans-10 and decreased the concentration of C18:2 cis-9,trans-11 in the rumen (6 h after feeding) for IA supplementation within the LF diets. The increase in $\mathrm{C} 18$ trans-10 isomers in the rumen did not affect milk C18 trans-10 isomers, although $\mathrm{C} 18$ trans- 11 isomers were decreased in milk for IA. This may suggest that ruminal concentration does not reflect the flow to and absorption in the small intestine, or that although IA supplementation increased alternate biohydrogenation in the rumen, the greater production of C18 trans-10 isomers in the rumen was not fully transferred to the mammary gland, so that direct inhibition of de novo synthesized FA by $\mathrm{C} 18$ trans-10 isomers did not occur. We do not know whether IA lowers the transfer of ruminal $\mathrm{C} 18$ trans-10 isomers into milk. However, IA increased rumen bacterial diversity and the diversity of functional features (i.e., enzymes; Lee et al., 2021), suggesting, at least in part, greater biohydrogenation in the rumen on a daily basis. This is likely supported 
by low concentration of linoleic acid (C18:2 cis-9, cis-12; major PUFA supplemented) in milk fat.

Although IA supplementation increased bacterial diversity, functional features in the rumen (Lee et al., 2021), and milk fat yield within the LF diets, the numerical decrease in NDF digestibility (3.2 percentageunit decrease) for $\mathrm{LF}-\mathrm{C}$ versus $\mathrm{HF}-\mathrm{C}$ was not alleviated by IA supplementation. The addition of IA (especially BCVFA) has been shown in several in vitro (Gorosito et al., 1985; Yang, 2002) and in vivo (Liu et al., 2018; Wang et al., 2019) studies to increase fiber digestibility because BCVFA can stimulate growth of cellulolytic bacteria in the rumen (Wang et al., 2019). Most studies that observed increased fiber digestibility with supplemental IA used diets with high NDF (e.g., $>40 \%$ of dietary DM; Liu et al., 2018; Wang et al., 2019). When BCVFA were infused intraruminally to lactating dairy cows fed a diet consisting of $<30 \%$ NDF of dietary DM, Klusmeyer et al. (1987) detected no difference in NDF digestibility, suggesting that stimulation of fiber degradation by IA could be related to fiber concentration in the diet. Furthermore, the lack of effect of IA on NDF digestibility may have been associated with dietary protein supply. In a study by Wang et al. (2018), when 2-methylbutyrate was provided to steers fed diets at 2 different dietary protein concentrations (about 10 and $13 \%$ in dietary DM), an interaction between 2-methylbutyrate and CP levels for NDF digestibility of corn straw (measured by an in situ technique in steers fed the treatment diets) was observed. The interaction indicated that NDF digestibility did not respond to 2-methylbutyrate supplementation with the high-CP diet, whereas NDF digestibility increased with the low-CP diet supplemented with 2-methylbutyrate. In the current study, the lack of an IA effect on NDF digestibility could be due to dietary protein supply (especially RDP; $10 \%$ of DM) being sufficient according to NRC (2001).

Potential postabsorptive effects of IA on increasing milk fat yield cannot be ruled out. In a recent study by Wang et al. (2019), supplementing $80 \mathrm{~g} / \mathrm{d}$ of BCVFA (i.e., IA without valerate) increased growth hormone concentration in plasma and increased milk fat content and yield. In another study by Liu et al. (2008), supplementing isobutyrate at an increasing rate of 20 , 40 , and $60 \mathrm{~g} / \mathrm{d}$ also linearly increased growth hormone concentrations in plasma. This increase in growth hormone agrees with the conclusion of the review by Andries et al. (1987). Growth hormone can partition nutrients away from body tissues to the mammary gland by decreasing mRNA expression of lipoprotein lipase (Beswick and Kennelly, 2000) and therefore increase the availability of glucose and lipids for milk synthesis (Hart, 1983; Bauman, 1999). In agreement, supplementing BCVFA at $80 \mathrm{~g} / \mathrm{d}$ increased expression of mRNA of key enzymes that are related to FA synthesis in mammary glands and increased de novo synthesis of FA (Eppard et al., 1985; Liu et al., 2018). Increased de novo synthesized FA in milk fat was observed in the current study. However, milk protein yield was not affected by IA supplementation within the LF diets, and neither dietary $\mathrm{N}$ excretion nor retained $\mathrm{N}$ were affected, suggesting that $\mathrm{N}$ metabolism was less responsive to IA in cows fed a moderate MFD-inducing diet or a diet with sufficient dietary protein supply according to NRC (2001). Liu et al. (2018) and Wang et al. (2019) reported that milk protein yield increased when cows were fed a diet with IA without valerate, but this could be a result of increased DMI in these studies. Results from previous studies likely suggest that milk protein yield is less responsive to IA when DMI is not altered.

\section{Effects of the Combination of HMTBa and IA Within the LF Diets}

We detected interactions between HMTBa and IA on several measures (milk yield, ECM, milk fat yield, and others). Further investigation indicates that the interactions occurred because the combination of HMTBa and IA did not have additive effects on these measures. For example, milk yield was greater for LF-HMTBa versus LF-C, but the difference was diminished when the combination of HMTBa and IA (i.e., LF-COMB) was used. Milk fat yield was increased for LF-HMTBa and LF-IA compared with LF-C, but milk fat yield was not additive for LF-COMB, resulting in a lack of additive effect on ECM as well. Lack of additive effect of LF-COMB does not support our hypothesis, even though supplementation of HMTBa or IA alleviated MFD apparently with different mechanisms. Lack of additive effects between HMTBa and IA were also observed in the rumen (i.e., rumen fermentation and bacterial community and diversity; Lee et al., 2021). For example, an increase in rumimal butyrate (molar proportion) by HMTBa was diminished (interaction $P$ $=0.03)$ when fed in combination with IA. Interactions also occurred $(P \leq 0.09)$ between HMTBa and IA on the relative abundances of some rumen bacterial taxa. In terms of ruminal effects, our companion paper (Lee et al., 2021) discusses aminotransferases that are common between BCAA (from BCVFA) and methionine (from HMTBa; Fernández and Zúniga, 2006) as a potential factor interrupting their co-metabolism by rumen bacteria when both are sufficiently available. Furthermore, because of potential postabsorptive effects of HMTBa and IA on MFD, as discussed previously, physiological 
and biological associations between HMTBa and IA cannot be ruled out. However, we did not find potential evidence in the literature for postabsorptive association between HMTB and IA, which needs to be further studied. In the current study, the use of HMTBa or IA alone was a better strategy to reduce moderate MFD than feeding a combination of HMTBa and IA.

\section{CONCLUSIONS}

Decreasing dietary NDF from 32 to $29 \%$ (forage NDF from 20.1 to $17.4 \%$ ) and increasing dietary starch content from 24 to $30 \%$ induced moderate MFD in cows producing $30 \mathrm{~kg} / \mathrm{d}$ of milk. Supplementing an MFD-inducing diet with HMTBa or IA increased milk fat yield, lowering risk of milk fat depression in field situations. However, supplementation of HMTBa increased milk yield without increasing milk fat content, whereas IA increased milk fat content without altering milk yield. Despite the different mechanism of increasing milk fat, the combination of HMTBa and IA did not have additive effects on milk fat yield. More studies are needed to understand biochemical and physiological interactions between HMTBa and IA.

\section{ACKNOWLEDGMENTS}

The project was supported by state and federal funds appropriated to the Ohio Agricultural Research and Development Center, The Ohio State University (Wooster, $\mathrm{OH}$ ), and partially funded by Zinpro Corporation Eden Prairie, MN). The authors thank P. A. Dieter (The Ohio State University, Wooster) for assistance with sample collection and laboratory assays and all staff at Krauss Dairy Research Center (Ohio Agricultural Research and Development Center, Wooster) for animal care. The isoacid product used in this study is a product in development at Zinpro Corporation, and it is the intent of Zinpro Corporation to eventually commercialize this product. One of the authors of this paper, M. T. Socha, is an employee of Zinpro Corporation. The authors have not stated any other conflicts of interest.

\section{REFERENCES}

Allen, M. S. 2000. Effects of diet on short-term regulation of feed intake by lactating dairy cattle. J. Dairy Sci. 83:1598-1624. https:// doi.org/10.3168/jds.S0022-0302(00)75030-2.

Allison, M. J., M. P. Bryant, and R. N. Doetsch. 1962a. Metabolic function of branched-chain volatile fatty acids, growth factors for ruminococci. I. Incorporation of isovalerate into leucine. J. Bacteriol. 83:523-532. https://doi.org/10.1128/JB.83.3.523-532.1962.

Allison, M. J., M. P. Bryant, I. Katz, and M. Keeney. 1962b. Metabolic function of branched-chain volatile fatty acids, growth factors for ruminococci. II. Biosynthesis of higher branched-chain fatty acids and aldehydes. J. Bacteriol. 83:1084-1093. https://doi.org/10 .1128/JB.83.5.1084-1093.1962.

Andries, J. I., F. X. Buysse, D. L. De Brabander, and B. G. Cottyn. 1987. Isoacids in ruminant nutrition: Their role in ruminal and intermediary metabolism and possible influences on performancesA review. Anim. Feed Sci. Technol. 18:169-180. https://doi.org/10 .1016/0377-8401(87)90069-1.

AOAC International. 2000. Official Methods of Analysis. 17th ed. Vol.1 and 2. AOAC International, Gaithersburg, MD.

Baldin, M., G. I. Zanton, and K. J. Harvatine. 2018. Effect of 2-hydroxy-4-(methylthio)butanoate (HMTBa) on risk of biohydrogenation-induced milk fat depression. J. Dairy Sci. 101:376-385. https: //doi.org/10.3168/jds.2017-13446.

Bauman, D. E. 1999. Bovine somatotropin and lactation: From basic science to commercial application. Domest. Anim. Endocrinol. 17:101-116. https://doi.org/10.1016/S0739-7240(99)00028-4.

Beswick, N. S., and J. J. Kennelly. 2000. Influence of bovine growth hormone and growth hormone-releasing factor on messenger RNA abundance of lipoprotein lipase and stearoyl-CoA desaturase in the bovine mammary gland and adipose tissue. J. Anim. Sci. 78:412-419. https://doi.org/10.2527/2000.782412x.

Dehority, B. A., H. W. Scott, and P. Kowaluk. 1967. Volatile fatty acid requirements of cellulolytic rumen bacteria. J. Bacteriol. 94:537543. https://doi.org/10.1128/JB.94.3.537-543.1967.

Dewanckele, L., P. G. Toral, B. Vlaeminck, and V. Fievez. 2020. Invited review: Role of rumen biohydrogenation intermediates and rumen microbes in diet-induced milk fat depression: An update. J. Dairy Sci. 103:7655-7681. https://doi.org/10.3168/jds.2019-17662.

Eppard, P. J., D. E. Bauman, J. Bitman, D. L. Wood, R. M. Akers, and W. A. House. 1985. Effect of dose of bovine growth hormone on milk composition: $\alpha$-lactalbumin, fatty acids, and mineral elements. J. Dairy Sci. 68:3047-3054. https://doi.org/10.3168/jds .S0022-0302(85)81200-5.

Feng, X., R. R. White, H. A. Tucker, and M. D. Hanigan. 2018. Metaanalysis of 2-hydroxy-4-methylthio-butanoic acid supplementation on ruminal fermentation, milk production, and nutrient digestibility. J. Dairy Sci. 101:7182-7189. https://doi.org/10.3168/jds .2017-13847.

Fernández, M., and M. Zúñiga. 2006. Amino acid catabolic pathways of lactic acid bacteria. Crit. Rev. Microbiol. 32:155-183. https:// doi.org/10.1080/10408410600880643.

Fuentes, M. C., S. Calsamiglia, P. W. Cardozo, and B. Vlaeminck. 2009. Effect of $\mathrm{pH}$ and level of concentrate in the diet on the production of biohydrogenation intermediates in a dual-flow continuous culture. J. Dairy Sci. 92:4456-4466. https://doi.org/10.3168/ jds.2008-1722.

Gorosito, A. R., J. B. Russell, and J. Van Soest. 1985. Effect of carbon- 4 and carbon- 5 volatile fatty acids on digestion of plant cell wall in vitro. J. Dairy Sci. 68:840-847. https://doi.org/10.3168/jds .S0022-0302(85)80901-2.

Hansen, W. P., D. E. Otterby, J. G. Linn, and J. D. Donker. 1991. Influence of forage type, ratio of forage to concentrate, and methionine hydroxy analog on performance of dairy cows. J. Dairy Sci 74:1361-1369. https://doi.org/10.3168/jds.S0022-0302(91)78291 $-\mathrm{X}$.

Hart, I. C. 1983. Endocrine control of nutrient partition in lactating ruminants. Proc. Nutr. Soc. 42:181-194.

Huber, J. T., R. S. Emery, W. G. Bergen, J. S. Liesman, L. Kung Jr., K. J. King, R. W. Gardner, and M. Checketts. 1984. Influences of methionine hydroxy analog on milk and milk fat production, blood serum lipids, and plasma amino acids. J. Dairy Sci. 67:2525-2531. https://doi.org/10.3168/jds.S0022-0302(84)81609-4.

Huhtanen, P., K. Kaustell, and S. Jaakkola. 1994. The use of internal markers to predict total digestibility and duodenal flow of nutrients in cattle given six different diets. Anim. Feed Sci. Technol. 48:211-227.

Jenkins, T. C. 2010. Technical note: Common analytical errors yielding inaccurate results during analysis of fatty acids in feed and 
digesta samples. J. Dairy Sci. 93:1170-1174. https://doi.org/10 $.3168 /$ jds.2009-2509.

Jenkins, T. C., and K. J. Harvatine. 2014. Lipid feeding and milk fat depression. Vet. Clin. North Am. Food Anim. Pract. 30:623-642. https://doi.org/10.1016/j.cvfa.2014.07.006.

Jenkins, T. C., R. J. Wallace, P. J. Moate, and E. E. Mosley. 2008. Board-invited review: Recent advances in biohydrogenation of unsaturated fatty acids within the rumen microbial ecosystem. J. Anim. Sci. 86:397-412. https://doi.org/10.2527/jas.2007-0588.

Klusmeyer, T. H., J. H. Clark, J. L. Vicini, M. R. Murphy, and G. C. Fahey. 1987. Effects of feeding or infusing ammonium-salts of volatile fatty-acids on ruminal fermentation, plasma characteristics, and milk-production of cows. J. Dairy Sci. 70:50-63.

Kone, P., P. F. Machado, and R. M. Cook. 1989. Effect of the combination of monensin and isoacids on rumen fermentation in vitro. $\mathrm{J}$. Dairy Sci. 72:2767-2771.

Lee, C., J. E. Copelin, T. Park, K. E. Mitchell, J. L. Firkins, M. T. Socha, and D. Luchini. 2021. Effects of diet fermentability and supplementation of 2-hydroxy-4-(methylthio)-butanoic acid and isoacids on milk fat depression: 2. Ruminal fermentation, fatty acid, and bacterial community structure. J. Dairy Sci. 104:15911603. https://doi.org/10.3168/jds.2020-18950.

Lee, C., D. L. Morris, and P. A. Dieter. 2019. Validating and optimizing spot sampling of urine to estimate urine output with creatinine as a marker in dairy cows. J. Dairy Sci. 102:236-245. https://doi .org/10.3168/jds.2018-15121.

Lee, C.. J. Oh, A. N. Hristov, K. Harvatine, M. Vazquez-Anon, and G. I. Zanton. 2015. Effect of 2-hydroxy-4-methylthio-butanoic acid on ruminal fermentation, bacterial distribution, digestibility, and performance of lactating dairy cows. J. Dairy Sci. 98:1234-1247. https://doi.org/10.3168/jds.2014-8904.

Liu, Q., C. Wang, G. Guo, W. J. Huo, S. L. Zhang, C. X. Pei, Y. L. Zhang, and H. Wang. 2018. Effects of branched-chain volatile fatty acids on lactation performance and mRNA expression of genes related to fatty acid synthesis in mammary gland of dairy cows. Animal 12:2071-2079. https://doi.org/10.1017/S1751731118000113.

Liu, Q., C. Wang, Y. Huang, K. Dong, W. Yang, and H. Wang. 2008. Effects of isobutyrate on rumen fermentation, urinary excretion of purine derivatives and digestibility in steers. Arch. Anim. Nutr. 62:377-388. https://doi.org/10.1080/17450390802327761.

Lobley, G. E., T. J. Wester, A. G. Calder, D. S. Parker, J. J. Dibner, and M. Vázquez-Añón. 2006. Absorption of 2-hydroxy-4-methylthiobutyrate and conversion to methionine in lambs. J. Dairy Sci. 89:1072-1080. https://doi.org/10.3168/jds.S0022-0302(06)72175 -0 .

Morris, D. L., L. R. Rebelo, P. A. Dieter, and C. Lee. 2018. Validating intrinsic markers and optimizing spot sampling frequency to estimate fecal outputs. J. Dairy Sci. 101:7980-7989. https://doi.org/ $10.3168 / j d s .2018-14717$.

Morris, D. L., A. W. Tebbe, W. P. Weiss, and C. Lee. 2019. Short communication: Effects of drying and analytical methods on nitrogen concentrations of feeds, feces, milk, and urine of dairy cows. J. Dairy Sci. 102:5212-5218. https://doi.org/10.3168/jds.2019-16256.

NRC. 2001. Nutrient Requirements of Dairy Cattle. 7th rev. ed. Natl. Acad. Sci., Washington, DC.

Papas, A. M., S. R. Ames, R. M. Cook, C. J. Sniffen, C. E. Polan, and L. Chase. 1984. Production responses of dairy-cows fed diets supplemented with ammonium-salts of iso C-4 and C-5 acids. J. Dairy Sci. 67:276-293. https://doi.org/10.3168/jds.S0022 $-0302(84) 81300-4$.

Peirce-Sandner, S. B., A. M. Papas, J. A. Rogers, T. F. Sweeney, K. A. Cummins, H. R. Conrad, and L. D. Muller. 1985. Supplementation of dairy-cow diets with ammonium-salts of volatile fatty acids. J. Dairy Sci. 68:2895-2907. https://doi.org/10.3168/jds.S0022 $-0302(85) 81183-8$

Piepenbrink, M. S., A. L. Marr, M. R. Waldron, W. R. Butler, T. R. Overton, M. Vázquez-Añón, and M. D. Holt. 2004. Feeding 2-hydroxy-4-(methylthio)-butanoic acid to periparturient dairy cows improves milk production but not hepatic metabolism. J. Dairy Sci. 87:1071-1084. https://doi.org/10.3168/jds.S0022 -0302(04)73253-1.
Pitta, D. W., N. Indugu, B. Vecchiarelli, M. Hennessy, M. Baldin, and K. J. Harvatine. 2020. Effect of 2-hydroxy-4-(methylthio) butanoate (HMTBa) supplementation on rumen bacterial populations in dairy cows when exposed to diets with risk for milk fat depression. J. Dairy Sci. 103:2718-2730. https://doi.org/10.3168/ jds.2019-17389.

Ramirez Ramirez, H. A., E. Castillo Lopez, K. J. Harvatine, and P. J. Kononoff. 2015. Fat and starch as additive risk factors for milk fat depression in dairy diets containing corn dried distillers grains with solubles. J. Dairy Sci. 98:1903-1914. https://doi.org/ 10.3168/jds.2014-8528.

Ramirez Ramirez, H. A., E. Castillo Lopez, C. J. R. Jenkins, N. D. Aluthge, C. Anderson, S. C. Fernando, K. J. Harvatine, and P. J. Kononoff. 2016. Reduced-fat dried distillers grains with solubles reduces the risk for milk fat depression and supports milk production and ruminal fermentation in dairy cows. J. Dairy Sci. 99:1912-1928. https://doi.org/10.3168/jds.2015-9712.

Rico, D. E., and K. J. Harvatine. 2013. Induction of and recovery from milk fat depression occurs progressively in dairy cows switched between diets that differ in fiber and oil concentration. J. Dairy Sci. 96:6621-6630. https://doi.org/10.3168/jds.2013-6820.

Rico, D. E., A. W. Holloway, and K. J. Harvatine. 2015. Effect of diet fermentability and unsaturated fatty acid concentration on recovery from diet-induced milk fat depression. J. Dairy Sci. 98:79307943. https://doi.org/10.3168/jds.2014-8990.

Rogers, J., W. Clark, D. Ferraro, A. Spearow, V. Blumer, C. Dougherty Jr., R. Cook, A. Jimenez, D. Dildey, and L. Armentano. 1989. Milk production of dairy cows fed ammonium and calcium salts of volatile fatty acids on 43 commercial dairy farms. J. Dairy Sci. 72:270-283. https://doi.org/10.3168/jds.S0022-0302(89)79106-2.

Sánchez-Duarte, J. I., K. F. Kalscheur, D. P. Casper, and A. D. Garcia. 2019. Performance of dairy cows fed diets formulated at 2 starch concentrations with either canola meal or soybean meal as the protein supplement. J. Dairy Sci. 102:7970-7979. https://doi .org/10.3168/jds.2018-15760.

Sjaunja, L. O., L. Baevre, L. Junkkarinen, J. Pedersen, and J. Setäla. 1990. A Nordic proposal for an energy corrected milk (ECM) formula. Pages 156-157 in Performance Recording of Animals: State of the Art, 1990: Proceedings of the 27th Biennial Session of the International Committee for Animal Recording (ICAR), Paris, France. J. A. M. van Arendonk, ed. Wageningen Academic Publishers, Wageningen, the Netherlands.

Tebbe, A. W., and W. P. Weiss. 2018. Evaluation of creatinine as a urine marker and factors affecting urinary excretion of magnesium by dairy cows. J. Dairy Sci. 101:5020-5032.

Troegeler-Meynadier, A., C. Palagiano, and F. Enjalbert. 2014. Effects of $\mathrm{pH}$ and fermentative substrate on ruminal metabolism of fatty acids during short-term in vitro incubation. J. Anim. Physiol. Anim. Nutr. (Berl.) 98:704-713. https://doi.org/10.1111/jpn .12128 .

Urrutia, N., R. Bomberger, C. Matamoros, and K. J. Harvatine. 2019. Effect of dietary supplementation of sodium acetate and calcium butyrate on milk fat synthesis in lactating dairy cows. J. Dairy Sci. 102:5172-5181. https://doi.org/10.3168/jds.2018-16024.

Urrutia, N., and K. J. Harvatine. 2017. Effect of conjugated linoleic acid and acetate on milk fat synthesis and adipose lipogenesis in lactating dairy cows. J. Dairy Sci. 100:5792-5804. https://doi.org/ 10.3168/jds.2016-12369.

Valadares, R. F. D., G. A. Broderick, S. C. V. Filho, and M. K. Clayton. 1999. Effect of replacing alfalfa silage with high moisture corn on ruminal protein synthesis estimated from excretion of total purine derivatives. J. Dairy Sci. 82:2686-2696. https://doi.org/10 3168/jds.S0022-0302(99)75525-6.

Vlaeminck, B., V. Fievez, S. Tamminga, R. J. Dewhurst, A. van Vuuren, D. De Brabander, and D. Demeyer. 2006. Milk odd- and branched-chain fatty acids in relation to the rumen fermentation pattern. J. Dairy Sci. 89:3954-3964. https://doi.org/10.3168/jds .S0022-0302(06)72437-7.

Wang, C., Q. Liu, G. Guo, W. J. Huo, C. X. Pei, S. L. Zhang, and W. Z. Yang. 2018. Effects of dietary protein levels and 2-methylbutyrate on ruminal fermentation, nutrient degradability, bacterial 
populations and urinary purine derivatives in Simmental steers. J. Anim. Physiol. Anim. Nutr. (Berl.) 102:611-619. https://doi.org/ 10.1111/.jpn.12797.

Wang, C., Q. Liu, G. Guo, W. J. Huo, Y. L. Zhang, C. X. Pei, and S. L. Zhang. 2019. Effects of rumen-protected folic acid and branched-chain volatile fatty acids supplementation on lactation performance, ruminal fermentation, nutrient digestion and blood metabolites in dairy cows. Anim. Feed Sci. Technol. 247:157-165. https://doi.org/10.1016/j.anifeedsci.2018.11.015.

Wang, C., Q. Liu, C. X. Pei, H. Y. Li, Y. X. Wang, H. Wang, Y. S. Bai, Z. G. Shi, X. N. Liu, and P. Li. 2012. Effects of 2-methylbutyrate on rumen fermentation, ruminal enzyme activities, urinary excretion of purine derivatives and feed digestibility in steers. Livest. Sci. 145:160-166. https://doi.org/10.1016/j.livsci.2012.01.013.

Weiss, W. P., N. R. St-Pierre, and L. B. Willett. 2009. Varying type of forage, concentration of metabolizable protein, and source of carbohydrate affects nutrient digestibility and production by dairy cows. J. Dairy Sci. 92:5595-5606. https://doi.org/10.3168/jds.2009 -2247 .
Yang, C.-M. J. 2002. Response of forage fiber degradation by ruminal microorganisms to branched-chain volatile fatty acids, amino acids, and dipeptides. J. Dairy Sci. 85:1183-1190. https://doi.org/10 .3168/jds.S0022-0302(02)74181-7.

Zanton, G. I., G. R. Bowman, M. Vazquez-Anon, and L. M. Rode. 2014. Meta-analysis of lactation performance in dairy cows receiving supplemental dietary methionine sources or postruminal infusion of methionine. J. Dairy Sci. 97:7085-7101. https://doi.org/10 $.3168 /$ jds.2014-8220.

\section{ORCIDS}

J. E. Copelin (® https://orcid.org/0000-0003-0549-8189

J. L. Firkins $\odot$ https://orcid.org/0000-0003-3518-1940

M. T. Socha $\odot$ https://orcid.org/0000-0002-0227-6591

C. Lee (ㄴ) https://orcid.org/0000-0002-4522-1232 